\title{
Petrogenesis of the South Sister, OR cone building eruptions
}

\author{
Laura E. WATERS ${ }^{1}$, Benjamin J. AndRews ${ }^{2}$, Holli M. \\ FREY $^{3}$ \\ ${ }^{1}$ EES, NM Institute of Mining and Technology, Socorro, NM \\ 87801, USA (*correspondence: laura.waters@nmt.edu) \\ ${ }^{2} \mathrm{NMNH}$, Smithsonian, Washington, DC, USA \\ ${ }^{3}$ Union College, Schenectady, NY 12308, USA
}

We conducted a petrologic study on two andesites (56-59

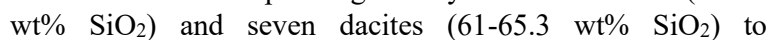
understand the conditions that gave rise to the pulse of intermediate volcanism that contructed the South Sister stratovolcano in light of the recent $(\sim 20 \mathrm{y})$ crustal deformation adjacent to the volcano. All samples erupted from the main edifice, except for two dacites that erupted in the peripheral field within $\sim 5 \mathrm{kya}$ of the cone building event. The andesites and dacites range in crystallinity $(\leq 15 \%$ and $\leq 5 \%$, respectively), and all are multiply saturated in six mineral phases (plg $+\mathrm{cpx}+\mathrm{opx}+\mathrm{ilm}+\mathrm{tmt}+\mathrm{ap})$. No hydrous phases were observed. We incorporated $\mathrm{Fe}-\mathrm{Ti}$ oxide compositions into a geo-thermometer [1] to derive pre-eruptive temperatures $\left(910 \pm 12^{\circ} \mathrm{C}\right.$ to $\left.981 \pm 24^{\circ} \mathrm{C}\right)$ and oxygen fugacities $(\triangle \mathrm{NNO}-0.1$ to +0.4$)$ for all samples. Application of a hygrometer [2] to plagioclase $\left(\sim \mathrm{An}_{35-70}\right)$ in these samples yeilds maximum pre-eruptive $\mathrm{H}_{2} \mathrm{O}$ contents of 3.0-4.8 wt $\%$. Orthopyroxne spans a range in composition $\left(\sim \mathrm{En}_{50-70}\right)$ despite relatively low modal abundances $(\leq 3 \%)$. Comparison of experimentally [3] documented effects of $\mathrm{H}_{2} \mathrm{O}$ on ${ }^{\mathrm{Fe}-\mathrm{Mg}_{\mathrm{K}}} \mathrm{K}_{\mathrm{D}}$ values for opx-melt with natural opx compositions also supports crystallization at low $\mathrm{H}_{2} \mathrm{O}$ contents ( $\leq 3.5 \mathrm{wt} \%$ ). Major, trace and REE analyses do not support mixing of magmatic end-members as an essential component for the South Sister intermediate melts, but they do suggest that the intermediate melts segregated from a crystalline residue containing: ol + opx/cpx + plag + hbl. The phenocryst assemblage suggests that crystallization occurred at low $\mathrm{H}_{2} \mathrm{O}$ contents in the shallow crust $(\leq 1.5 \mathrm{~kb})$, at temperatures above hornblende stability. Because sample geochemistry (i.e., Dy*) requires hornblende to be present in the source of the intermediate magmas, we infer that the magmatic source of the intermediate melts is deeper than the depth of phenocryst crystallization. Comparsion of major element patterns with experiments show that the South Sister geochemistry can be produced from a mafic source at depths as shallow as $\sim 2 \mathrm{~kb}$ $(\sim 6 \mathrm{~km})$, given $\mathrm{H}_{2} \mathrm{O}$-saturated conditions.

[1] Ghiorso and Evans (2008) AJS 308, 957-1039. [2] Waters and Lange (2015) AmMin 100, 2172-2184. [3] Waters and Lange (2017) CMP 172. 